\title{
ANALISIS DAYA DUKUNG DAN KEBUTUHAN LAHAN PERTANIAN DI KABUPATEN PURWAKARTA TAHUN 2028
}

\author{
Iman Diva Jakapratama ${ }^{1 *}$, Muhammad Zidan ${ }^{2}$, Nilan Sinta Alfiah ${ }^{3}$, Shafa Dinda A R R $^{4}$ \\ 1, 2, 3,4 Program Studi Sains Informasi Geografi, Fakultas Pendidikan Ilmu Pengetahuan Sosial, \\ Universitas Pendidikan Indonesia \\ *shafadindaar@upi.edu
}

\begin{tabular}{|c|c|}
\hline \multicolumn{2}{|c|}{ INFO ARTIKEL } \\
\hline Riwayat $A r$ & \\
\hline Dikirim & : 29-07-2020 \\
\hline Disetujui & $22-01-2021$ \\
\hline Diterbitkan & : 31-01-2021 \\
\hline
\end{tabular}

Kata Kunci :

Kekeringan, Indeks

Kesehatan Vegetasi
Abstract: Agriculture is the main source of livelihood in some rural communities of Purwakarta Regency. The carrying capacity of land must be considered very much because it affects the sustainability of life and human welfare. Analysis of the carrying capacity of agricultural land can solve problems of land change and food security. This study will discuss the calculation of the need for agricultural land in Purwakarta Regency based on the calculation of population projections for the next 10 years, using data in 2018. The method used in this research is quantitative descriptive method. The process of searching, collecting and analyzing data was carried out using literature studies from various reliable sources. The analysis technique used to determine the carrying capacity of agricultural land uses a mathematical formula from the combined concept of the theory of Odum, Christeiler, Ebener Howard, and Issard in Soeharjo and Tukiran (1990) in Moniaga (2011), calculation of the Optimal Population (JPO), and calculations Need for Agricultural Land (KPLR). The results of this study are the KLPR 2028 map which shows the results of varying levels of land carrying capacity caused by data factors of harvested area, production, and population in each district depending on the commodity. The results of the calculation of the optimal population $(J P O)$ in several sub-districts of Purwakarta Regency, if adjusted for their commodities, are still less than the total population recorded in each district. The results of the calculation of the need for agricultural land from the JPO 2028 and KPLR 2028 calculations show that Jatiluhur, Maniis, Sukatani, Purwakarta, Babakancikako, Campaka, and Bungursari sub-districts cannot become food self-sufficiency areas by 2028. Meanwhile, other sub-districts can still be food self-sufficient. for 2028 because the needs can still be met from the existing harvested area.

Abstrak: Pertanian menjadi sumber mata pencaharian utama di sebagian masyarakat pedesaan Kabupaten Purwakarta. Daya dukung lahan harus sangat diperhatikan karena berpengaruh dengan keberlangsungan kehidupan dan kesejahteraan manusia. Analisis daya dukung lahan pertanian dapat memecahkan masalah perubahan lahan dan ketahanan pangan. Penelitian ini akan membahas mengenai perhitungan kebutuhan lahan pertanian di Kabupaten Purwakarta berdasarkan perhitungan proyeksi penduduk 10 tahun ke depan, dengan menggunakan data pada tahun 2018. Metode yang digunakan dalam penelitian ini yakni dengan metode deskriptif kuantitatif. Proses pencarian, pengumpulan, dan analisis data dilakukan dengan menggunakan studi kepustakaan dari berbagai sumber terpecaya. Teknik 
analisis yang digunakan untuk menentukan daya dukung lahan pertanian mengunakan rumus matematika dari konsep gabungan atas teori Odum, Christeiler, Ebener Howard, dan Issard dalam Soeharjo dan Tukiran (1990) dalam Moniaga (2011), perhitungan Jumlah Penduduk Optimal (JPO), dan perhitungan Kebutuhan Lahan Pertanian (KPLR). Hasil dari penelitian ini adalah Peta KLPR 2028 yang menunjukan hasil tingkat daya dukung lahan yang bervariasi yang disebabkan oleh faktor data luas panen, produksi, dan jumlah penduduk pada tiap kecamatan tergantung pada komoditasnya. Hasil perhitungan jumlah penduduk optimal (JPO) di beberapa kecamatan Kabupaten Purwakarta apabila disesuaikan dengan komoditasnya masih lebih sedikit dibandingkan dengan jumlah penduduk yang terdata pada masing-masing kecamatan. Hasil perhitungan kebutuhan lahan pertanian dari perhitungan JPO 2028 dan KPLR 2028 yang menunjukan bahwa kecamatan Jatiluhur, Maniis, Sukatani, Purwakarta, Babakancikako, Campaka, dan Bungursari tidak bisa menjadi wilayah swasembada pangan pada tahun 2028. Sedangkan untuk kecamatan yang lain masih bisa menjadi swasembada pangan untuk 2028 karena kebutuhan masih dapat terpenuhi dari luas lahan panen yang ada.

\section{PENDAHULUAN}

Lahan merupakan suatu luasan di permukaan bumi yang mecakup lingkungan fisik (iklim, topografi, tanah dan air) dan biotik (manusia, hewan dan tumbuhan) yang dapat dimanfaatkan untuk mendukung keberlangsungan kehidupan dan kesejahteraan manusia. Lahan harus dimanfaatkan oleh manusia untuk suatu kepentingan dari lingkungan hidup menjadi lingkungan terbangun.

Daya dukung lahan adalah jumlah penduduk yang dapat didukung atau disokong oleh suatu luas sumberdaya lahan pada lingkungan tertentu dalam keadaan makmur, sesuai dengan teknologi dan pengelolaan usahatani yang dilakukan petani (Soerianegara, 1978). Daya dukung lahan harus sangat diperhatikan karena berpengaruh dengan keberlang-sungan kehidupan dan kesejahteraan manusia.

Secara berkelanjutan, meningkat-nya pertumbuhan penduduk yang cepat menimbulkan berbagai masalah. Peningkatan pembangunan yang terus-menerus juga menimbulkan adanya alih fungsi lahan pertanian ke lahan non pertanian.

Semakin banyak jumlah penduduk kebutuhan akan pangan, sandang, dan papan semakin meningkat. Lahan menjadi hal yang sangat penting untuk dimanfaatkan terutama lahan pertanian. Permasalahan mendasar dari sektor pertanian adalah semakin menyusutnya lahan pertanian akibat alih fungsi lahan (BAPPENAS, 2015). Tingginya alih fungsi lahan pertanian menimbulkan masalah terhadap ketahanan pangan di suatu wilayah.

Pertanian menjadi sumber mata pencaharian utama di sebagian masyarakat pedesaan Kabupaten Purwakarta. Menurut hasil sensus pertanian tahun 2013 jumlah rumah tangga pertanian di Kabupaten Purwakarta sebanyak 73.155 rumah tangga yang terdiri dari sub sektor tanaman pangan sebanyak 56.495 rumah tangga, holtikultura sebanyak 32.796 rumah tangga, perkebunan sebanyak 21.723 rumah tangga, kehutanan sebanyak 30.594 rumah tangga, jasa pertanian sebanyak 3.091 rumah tangga dan sisanya pada sub sektor peternakan dan perikanan.

Letak yang strategis Kabupaten Purwakarta juga menjadi faktor yang menguntungkan untuk pemasaran hasil-hasil pertanian dari Purwakarta keluar daerah lainnya. Pembangun sektor pertanian saat ini juga masih menjadi perhatian serius untuk Pemerintah Kabupaten Purwakarta. Karena sektor pertanian diharapkan akan berdapak positif pada pertumbuhan ekonomi daerah, menjamin produksi dan ketersediaan panga n bagi masyarakat Purwakarta.

Kebijakan pembangunan pertanian selalu didominasi dengan kebijakan perberasan (Nurmalia, dkk.2007). Beras yang baik dihasikan dari lahan pertanian yang baik. Analisis daya 
dukung lahan pertanian dapat memecahkan masalah perubahan lahan dan ketahanan pangan. McCall (1955) mengemukakan bahwa yang dimaksud daya dukung adalah alat untuk menganalisis penggunaan tanah khususnya untuk pertanian dan data populasi yang sistematis. Dengan mengetahui tingkat dukungan dari suatu area / lahan maka dapat diperkirakan berbagai kemungkinan yang akan terjadi atau memperkirakan tingkat kebutuhan penduduk yang disesuaikan dengan kondisi lahan yang ada (Muta'ali, 2015).

Pada artikel membahas mengenai perhitungan kebutuhan lahan pertanian di Kabupaten Purwakarta berdasarkan perhitungan proyeksi penduduk 10 tahun ke depan, dengan menggunakan data pada tahun 2018 .

\section{METODE}

Metode yang digunakan dalam penelitian ini yaitu metode deskriptif kuantitatif. Proses pencarian, pengumpulan, dan analisis data dilakukan dengan menggunakan studi kepustakaan dari berbagai sumber terpecaya seperti, Badan Pusat Statistik Kabupaten Purwakarta, Ina-Geoportal, dan Google Scholar sebagai tempat mencari referensi jurnal bacaan yang selanjutnya jurnal/ artikel ilmiah/ buku tersebut dianalisis untuk menjelaskan temuan, hasil, ide atau pendapat, dan konsep atau teori yang berhubungan dengan kebutuhan lahan pertanian di Kabupaten Purwakata pada penelitian ini.

Data - data yang dikumpulkan sebagai bahan penelitian ini antara lain: Jumlah penduduk per kecamatan di Kabupaten Purwakarta; luas panen lahan pertanian pada komoditas padi, jagung, ubi kayu, dan ubi jalar per hektar; produksi panen pada komoditas padi, jagung, ubi kayu, dan ubi jalar per ton; data kalori per kilogram dari komoditas padi, jagung, ubi kayu, dan ubi jalar; data laju pertumbuhan penduduk per kecamatan; dan data batas administrasi Kabupaten Purwakarta sebagai bahan untuk membuat peta.

Peralatan yang digunakan dalam penelitian ini dibedakan menjadi peralatan untuk pengolahan data dan anlisis data serta untuk pembuatan peta, peralatannya antara lain:
2. Microsoft Excel 2016

3. ArcMap 10.3

Teknik analisis yang digunakan dalam menentukan daya dukung lahan pertanian digunakn rumus matematika dari konsep gabungan atas teori Odum, Christeiler, Ebener Howard, dan Issard dalam Soeharjo dan Tukiran (1990) dalam Moniaga (2011) yaitu:

$$
\phi=\frac{\mathbf{X}}{\mathbf{K}}
$$

Keterangan:

$\Phi=$ Tingkat daya dukung lahan pertanian

$\mathrm{X}=$ Luas panen tanaman pangan per kapita

$\mathrm{K}=$ Luas lahan untuk swasembada pangan

Dengan rumus $\mathrm{X}$ dan $\mathrm{K}$ berasal dari:

$$
\begin{aligned}
& \mathbf{X}=\frac{\text { Luas Panen }(\text { Ha) }}{\text { Jumlah Penduduk (Jiwa) }} \\
& \mathbf{K}=\frac{\text { Kebutuhan Fisik Minimum (KFM) }}{\text { Produktivitas Tanaman Pangan }}
\end{aligned}
$$

Perhitungan nilai KFM (Kebutuhan Fisik Minimum) dengan cara mengonversi kebutuhan pangan manusia yang dinyatakan dalam bentuk kalori ke bentuk ton per tahun yang disesuaikan dari macam komoditasnya.

1. $1 \mathrm{~kg}$ beras $=3.600$ kalori

2. $1 \mathrm{~kg}$ jagung $=3.610$ kalori

3. $1 \mathrm{~kg}$ ubi kayu $=1.460$ kalori

4. $1 \mathrm{~kg}$ ubi jalar $=1.230$ kalori

Berdasarkan data FAO dan Permenakertrans No. 13 tahun 2012, nilai KFM masyarakat yaitu sebesar 1.500 kalori/hari sehingga jika dihitung dengan menggunakan jenis komoditasnya yaitu sebagai berikut.

- Beras $1 \mathrm{~kg}$ mengandung 3.600 kalori, sehingga 1.500 kalori itu setara dengan $0,416 \mathrm{~kg}$ beras/hari maka KFM dalam setahun adalah $152,083 \mathrm{~kg}$ beras/tahun $(0,1521$ ton/tahun).

- Jagung $1 \mathrm{~kg}$ mengandung 3.610 kalori, sehingga 1.500 kalori itu setara dengan $0,4155 \mathrm{~kg}$ jagung/hari maka KFM dalam setahun adalah $151,662 \mathrm{~kg}$ jagung/tahun $(0,151662$ ton/tahun).

1. Microsoft Word 2016 
- Ubi Kayu $1 \mathrm{~kg}$ mengandung 1.460 kalori, sehingga 1.500 kalori itu setara dengan 1,0274 kg ubi kayu/hari maka KFM dalam setahun adalah $375 \mathrm{~kg}$ ubi kayu/tahun (0,375 ton/tahun).

- Ubi Jalar $1 \mathrm{~kg}$ mengandung 1.230 kalori, sehingga 1.500 kalori itu setara dengan 1,2195 $\mathrm{kg}$ ubi jalar/hari maka KFM dalam setahun adalah $445,122 \mathrm{~kg}$ ubi jalar/tahun $(0,445122$ ton/tahun).

Produktivitas Tanaman Pangan (ton/ha) dapat dicari dengan menggunakan rumus:

\section{Luas Panen (Ha) \\ $=\overline{\text { Produksi Tanaman Pangan (/ ton) }}$}

Berdasarkan hasil nilai dari perhitungan Daya Dukung Lahan kemudian diklasifikasikan menjadi 3 kelas, yaitu:

- Kelas I jika nilai $\phi>2,47$ artinya daya dukung lahan pertanian tinggi dan wilayah tersebut mampu swasembada pangan dan memberikan kehidupan yang layak bagi bagi penduduknya;

- Kelas II jika nilai $1<\phi<2,47$ artinya daya dukung lahan optimal dan wilayah tersebut mampu swasembada pangan, namun belum mampu memberikan kehidupan yang layak bagi penduduknya; dan

- Kelas III jika nilai $\phi<1$ artinya daya dukung lahan pertanian rendah dan wilayah tersebut belum mampu swasembada pangan serta belum mampu memberikan kehidupanyang layak bagi penduduknya.

Setelah diketahui daya dukung lahan pertanian maka perlu juga mengetahui jumlah penduduk optimal (JPO) yaitu jumlah penduduk yang mampu didukung oleh hasil tanaman pangan dari

upaya peningkatan luas dan kualitas lahan pertanian. Berikut rumus menghitung Kebutuhan Lahan Pertanian (KLPR):

$$
\text { KLPR }=\frac{(\text { KPB x Po })(1+r n)}{\operatorname{Pr} \times 0,632}
$$

Keterangan:

KLPR = Kebutuhan Lahan Pertanian

$\mathrm{KPB}=$ Kebutuhan pangan beras per kapita sebesar 154,1 kg/kapita/tahun (Menurut Badan Ketahanan Pangan)

Po $=$ Jumlah penduduk awal tahun dasar lahan pertanian yang ada di wilayah yang bersangkutan. Berikut rumus untuk menghitung Jumlah Penduduk Optimal (JPO):

\section{JPO = Daya Dukung Lahan $x$ Jumlah Penduduk}

Penelitian ini bertujuan untuk mengetahui kebutuhan lahan pertanian di Kabupaten Purwakarta berdasarkan perhitungan proyeksi penduduk 10 tahun ke depan sehingga selain daya dukung lahan dan jumlah penduduk optimal diperlukan juga menghitung perkiraan jumlah penduduk 10 tahun ke depan dengan menggunakan rumus proyeksi penduduk sebagai berikut.

$$
\text { Pn }=\text { Po }\{1+(\text { r.n })\}
$$

Keterangan:

$\mathrm{Pn}=$ Jumlah penduduk setelah $\mathrm{n}$ tahun ke depan / Proyeksi Penduduk

Po $=$ Jumlah penduduk tahun awal

$\mathrm{r}$ = Angka pertumbuhan penduduk

$\mathrm{n}$ = Jangka waktu dalam tahun

Rumus proyeksi penduduk ini dengan pertimbangan bahwa pertambahan penduduk sampai 10 tahun ke depan di tahun 2028 adalah tetap. Selain itu, dalam penelitian ini data luas lahan panen dan jumlah produksi panen dianggap statis seperti tahun - tahun sebelum proyeksi. Setelah mengetahui JPO yang mampu didukung oleh lahan pertanian maka selanjutnya yang perlu diketahui adalah kebutuhan akan lahan pertanian pada tahun proyeksi yang fungsinya dapat sebagai acuan perencanaan mengenai upaya $r=$ Angka pertumbuhan penduduk per kecamatan

$\mathrm{n}=$ Tahun proyeksi

Pr $=$ Produksi lahan rata - rata per hektar (kg/ha)

$0,63=$ Konstanta pengubah dari padi ke beras

KLPR yang dipakai sebagai hasil dari penelitian ini nanti hanya untuk komoditas padi karena diantara semua komoditas, padi yang sudah diolah menjadi beras merupakan salah satu bahan makanan 
sumber energi sekaligus bahan makanan pokok bagi sebagian besar masyarakat Indonesia. Menurut Suryana (2003), beras tetap dominan sebagai makanan pokok karena beras merupakan sumber energi maupun sumber nutrisi yang lebih baik dibandingkan dengan jenis makanan pokok lainnya.

\section{HASIL DAN PEMBAHASAN}

Tabel 1. Jumlah Penduduk, Luas Panen, Produktivitas, dan Produksi Padi di Kabupaten Purwakarta 2018.

\begin{tabular}{|c|c|c|c|c|c|c|}
\hline \multirow{2}{*}{ No } & \multirow{2}{*}{ Kecamatan } & \multicolumn{4}{|c|}{ Jumlah Seluruh Padi (Sawah+Ladang) } & \multirow{2}{*}{ Jumlah Penduduk } \\
\hline & & Luas Panen (ha) & Produktivitas (kw) & Produktivitas (ton) & Produksi (ton) & \\
\hline 1 & Jatiluhur & 1146 & 60,60209424 & 6,060209424 & 6945 & 70166 \\
\hline 2 & Sukasari & 1263 & 59,16864608 & 5,916864608 & 7473 & 14631 \\
\hline 3 & Maniis & 1441 & 58,97293546 & 5,897293546 & 8498 & 34311 \\
\hline 4 & Tegalwaru & 2804 & 60,2532097 & 6,02532097 & 16895 & 45954 \\
\hline 5 & Plered & 3576 & 61,08221477 & 6,108221477 & 21843 & 78361 \\
\hline 6 & Sukatani & 2750 & 60,23636364 & 6,023636364 & 16565 & 69514 \\
\hline 7 & Darangdan & 4547 & 60,75654278 & 6,075654278 & 27626 & 64356 \\
\hline 8 & Bojong & 2692 & 61,01040119 & 6,101040119 & 16424 & 47930 \\
\hline 9 & Wanayasa & 3563 & 60,35363458 & 6,035363458 & 21504 & 42303 \\
\hline 10 & Kiarapedes & 3324 & 60,42719615 & 6,042719615 & 20086 & 23249 \\
\hline 11 & Pasawahan & 2766 & 61,08821403 & 6,108821403 & 16897 & 44392 \\
\hline 12 & Pondoksalam & 4528 & 61,12853357 & 6,112853357 & 27679 & 27470 \\
\hline 13 & Purwakarta & 1189 & 60,84945332 & 6,084945332 & 7235 & 191776 \\
\hline 14 & Babakancikao & 1299 & 59,79984604 & 5,979984604 & 7768 & 57494 \\
\hline 15 & Campaka & 1889 & 59,55002647 & 5,955002647 & 11249 & 48681 \\
\hline 16 & Cibatu & 3657 & 59,78671042 & 5,978671042 & 21864 & 28756 \\
\hline 17 & Bungursari & 1553 & 58,91178364 & 5,891178364 & 9149 & 64060 \\
\hline
\end{tabular}

Tabel 2. Jumlah Penduduk, Luas Panen, Produktivitas, dan Produksi Jagung di Kabupaten Purwakarta 2018.

\begin{tabular}{|c|c|c|c|c|c|c|}
\hline \multirow{2}{*}{ No } & \multirow{2}{*}{ Kecamatan } & \multicolumn{4}{|c|}{ Jagung } & \multirow{2}{*}{ Jumlah Penduduk } \\
\hline & & Luas Panen (ha) & Produktivitas (kw) & Produktivitas (ton) & Produksi (ton) & \\
\hline 1 & Jatiluhur & 80 & 53,63 & 5,363 & 429 & 70166 \\
\hline 2 & Sukasari & 33 & 53,64 & 5,364 & 177 & 14631 \\
\hline 3 & Maniis & 224 & 53,48 & 5,348 & 1198 & 34311 \\
\hline 4 & Tegalwaru & 78 & 53,59 & 5,359 & 418 & 45954 \\
\hline 5 & Plered & 127 & 53,78 & 5,378 & 683 & 78361 \\
\hline 6 & Sukatani & 76 & 53,42 & 5,342 & 406 & 69514 \\
\hline 7 & Darangdan & 66 & 53,79 & 5,379 & 355 & 64356 \\
\hline 8 & Bojong & 57 & 53,68 & 5,368 & 306 & 47930 \\
\hline 9 & Wanayasa & 44 & 53,64 & 5,364 & 236 & 42303 \\
\hline 10 & Kiarapedes & 109 & 53,58 & 5,358 & 584 & 23249 \\
\hline 11 & Pasawahan & 16 & 53,75 & 5,375 & 86 & 44392 \\
\hline 12 & Pondoksalam & 12 & 53,33 & 5,333 & 64 & 27470 \\
\hline 13 & Purwakarta & 12 & 53,33 & 5,333 & 64 & 191776 \\
\hline 14 & Babakancikao & 15 & 54 & 5,4 & 81 & 57494 \\
\hline 15 & Campaka & 24 & 53,75 & 5,375 & 129 & 48681 \\
\hline 16 & Cibatu & 72 & 53,61 & 5,361 & 386 & 28756 \\
\hline 17 & Bungursari & 85 & 53,65 & 5,365 & 456 & 64060 \\
\hline
\end{tabular}

Tabel 3. Jumlah Penduduk, Luas Panen, Produktivitas, dan Produksi Ubi Kayu di Kabupaten Purwakarta 2018. 
Available at https://ejurnalunsam.id/index.php/jsg/article/view/2505

\begin{tabular}{|c|c|c|c|c|c|c|}
\hline \multirow{2}{*}{ No } & \multirow{2}{*}{ Kecamatan } & \multicolumn{4}{|c|}{ Ubi Kayu } & \multirow{2}{*}{ Jumlah Penduduk } \\
\hline & & Luas Panen (ha) & Produktivitas (kw) & Produktivitas (ton) & Produksi (ton) & \\
\hline 1 & Jatiluhur & 130 & 196,85 & 19,685 & 2559 & 70166 \\
\hline 2 & Sukasari & 7 & 198,57 & 19,857 & 139 & 14631 \\
\hline 3 & Maniis & 25 & 198,4 & 19,84 & 496 & 34311 \\
\hline 4 & Tegalwaru & 80 & 197,75 & 19,775 & 1582 & 45954 \\
\hline 5 & Plered & 149 & 197,99 & 19,799 & 2950 & 78361 \\
\hline 6 & Sukatani & 425 & 197,44 & 19,744 & 8391 & 69514 \\
\hline 7 & Darangdan & 35 & 198,29 & 19,829 & 694 & 64356 \\
\hline 8 & Bojong & 42 & 198,1 & 19,81 & 832 & 47930 \\
\hline 9 & Wanayasa & 190 & 197,95 & 19,795 & 3761 & 42303 \\
\hline 10 & Kiarapedes & 84 & 198,81 & 19,881 & 1670 & 23249 \\
\hline 11 & Pasawahan & 82 & 197,07 & 19,707 & 1616 & 44392 \\
\hline 12 & Pondoksalam & 3 & 196,67 & 19,667 & 59 & 27470 \\
\hline 13 & Purwakarta & 17 & 197,65 & 19,765 & 336 & 191776 \\
\hline 14 & Babakancikao & 50 & 197,8 & 19,78 & 989 & 57494 \\
\hline 15 & Campaka & 30 & 198 & 19,8 & 594 & 48681 \\
\hline 16 & Cibatu & 70 & 198 & 19,8 & 1386 & 28756 \\
\hline 17 & Bungursari & 58 & 197,93 & 19,793 & 1148 & 64060 \\
\hline
\end{tabular}

Tabel 4. Jumlah Penduduk, Luas Panen, Produktivitas, dan Produksi Ubi Jalar di Kabupaten Purwakarta 2018.

\begin{tabular}{|c|c|c|c|c|c|c|}
\hline \multirow{2}{*}{ No } & \multirow{2}{*}{ Kecamatan } & \multicolumn{4}{|c|}{ Ubi Jalar } & \multirow{2}{*}{ Jumlah Penduduk } \\
\hline & & Luas Panen (ha) & Produktivitas $(\mathrm{kw})$ & \begin{tabular}{|l|} 
Produktivitas (ton) \\
\end{tabular} & Produksi (ton) & \\
\hline 1 & Jatiluhur & 0 & 0 & 0 & 0 & 70166 \\
\hline 2 & Sukasari & 1 & 0 & 0 & 15 & 14631 \\
\hline 3 & Maniis & 38 & 145,26 & 14,526 & 552 & 34311 \\
\hline 4 & Tegalwaru & 8 & 145 & 14,5 & 116 & 45954 \\
\hline 5 & Plered & 12 & 145,83 & 14,583 & 175 & 78361 \\
\hline 6 & Sukatani & 4 & 14 & 1,4 & 58 & 69514 \\
\hline 7 & Darangdan & 34 & 145,59 & 14,559 & 495 & 64356 \\
\hline 8 & Bojong & 19 & 145,26 & 14,526 & 276 & 47930 \\
\hline 9 & Wanayasa & 17 & 145,88 & 14,588 & 248 & 42303 \\
\hline 10 & Kiarapedes & 31 & 145,81 & 14,581 & 452 & 23249 \\
\hline 11 & Pasawahan & 29 & 145,17 & 14,517 & 421 & 44392 \\
\hline 12 & Pondoksalam & 2 & 145 & 14,5 & 29 & 27470 \\
\hline 13 & Purwakarta & 3 & 146,67 & 14,667 & 44 & 191776 \\
\hline 14 & Babakancikao & 7 & 0 & 0 & 102 & 57494 \\
\hline 15 & Campaka & 0 & 0 & 0 & 0 & 48681 \\
\hline 16 & Cibatu & 20 & 145,5 & 14,55 & 291 & 28756 \\
\hline 17 & Bungursari & 0 & 0 & 0 & 0 & 64060 \\
\hline
\end{tabular}

Tabel 5. Daya Dukung Lahan Tanaman Padi, Jagung, Ubi Kayu, dan Ubi Jalar Tahun 2018. 


\begin{tabular}{|c|c|c|c|c|c|c|c|c|c|}
\hline \multirow{2}{*}{ No } & \multirow{2}{*}{ Kecamatan } & \multicolumn{2}{|c|}{ Padi } & \multicolumn{2}{|c|}{ Jagung } & \multicolumn{2}{|c|}{ Ubi Kayu } & \multicolumn{2}{|c|}{ Ubi Jalar } \\
\hline & & DDL & Kelas & DDL & Kelas & DDL & Kelas & DDL & Kelas \\
\hline 1 & Jatiluhur & 0,6508 & 3 & 0,0403 & 3 & 0,0973 & 3 & $\mathrm{O}$ & 3 \\
\hline 2 & Sukasari & 3,3585 & 1 & 0,0798 & 3 & 0,0253 & 3 & 0 & 3 \\
\hline 3 & Maniis & 1,6286 & 2 & 0,2302 & 3 & 0,0385 & 3 & 0,0361 & 3 \\
\hline 4 & Tegalwaru & 2,4174 & 2 & 0,0600 & 3 & 0,0918 & 3 & 0,0057 & 3 \\
\hline 5 & Plered & 1,8329 & 2 & 0,0575 & 3 & 0,1004 & 3 & 0,0050 & 3 \\
\hline 6 & Sukatani & 1,5669 & 2 & 0,0385 & 3 & 0,3219 & 3 & 0,0002 & 3 \\
\hline 7 & Darangdan & 2,8226 & 1 & 0,0364 & 3 & 0,0288 & 3 & 0,0173 & 3 \\
\hline 8 & Bojong & 2,2532 & 2 & 0,0421 & 3 & 0,0463 & 3 & 0,0129 & 3 \\
\hline 9 & Wanayasa & 3,3425 & 1 & 0,0368 & 3 & 0,2371 & 3 & 0,0132 & 3 \\
\hline 10 & Kiarapedes & 5,6808 & 1 & 0,1656 & 3 & 0,1915 & 3 & 0,0437 & 3 \\
\hline 11 & Pasawahan & 2,5028 & 1 & 0,0128 & 3 & 0,0971 & 3 & 0,0213 & 3 \\
\hline 12 & Pondoksalam & 6,6254 & 1 & 0,0154 & 3 & 0,0057 & 3 & 0,0024 & 3 \\
\hline 13 & Purwakarta & 0,2481 & 3 & 0,0022 & 3 & 0,0047 & 3 & 0,0005 & 3 \\
\hline 14 & Babakancikao & 0,8884 & 3 & 0,0093 & 3 & 0,0459 & 3 & 0 & 3 \\
\hline 15 & Campaka & 1,5194 & 3 & 0,0175 & 3 & 0,0325 & 3 & $\mathrm{O}$ & 3 \\
\hline 16 & Cibatu & 4,9994 & 3 & 0,0885 & 3 & 0,1285 & 3 & 0,0227 & 3 \\
\hline 17 & Bungursari & 0,9391 & 3 & 0,0469 & 3 & 0,0478 & 3 & $\mathrm{O}$ & 3 \\
\hline
\end{tabular}

\section{Daya Dukung Lahan Tanaman Pangan}

Perhitungan daya dukung lahan pada komoditas padi, jagung, ubi kayu, dan ubi jalar untuk tiap kecamatan di kabupaten purwakarta tahun 2018, memiliki hasil tingkat daya dukung lahan yang bervariasi yang disebabkan oleh faktor data luas swasembada pangan ataupun yang tidak, sesuai dengan tingkat kelasnya menurut kriteria kelas di subbab metode.

Pada daya dukung lahan padi, Kecamatan Sukasari, Kecamatan Darangdan, Kecamatan Wanayasa, Kecamatan Kiarapedes, Kecamatan Pasawahan, dan Kecamatan Pondoksalam merupakan kecamatan yang tergolong kelas 1 yang artinya wilayah yang mampu swasembada pangan dan mampu memberikan kehidupan yang layak bagi penduduknya, untuk Kecamatan Maniis, Tegalwru, Plered, Sukatani, dan Bojong tergolong kelas 2 yang artinya daya dukung lahan optimal dan wilayah tersebut mampu swasembada pangan, namun belum mampu memberikan kehidupan yang layak bagi penduduknya, dan untuk Kecamatan Jatiluhur, Purwakarta, Babakancikao, panen, produksi, dan jumlah penduduk pada tiap kecamatan tergantung pada komoditasnya, data dapat dilihat di tabel 1 4.

Dari tabel 5, dapat diklasifikasikan kecamatan yang mampu memberikan kehidupan yang mampu menjadi Campaka, Cibatu, dan Bungursari tergolong kelas 3 artinya daya dukung lahan pertanian rendah dan wilayah tersebut belum mampu swasembada pangan serta belum mampu memberikan kehidupanyang layak bagi penduduknya. Sedangkan untuk komoditas jagung, ubi kayu, dan ubi jalar di seluruh kecamatan memiliki daya dukung lahan golongan 3 artinya daya dukung lahan pertanian rendah.

Jika daya dukung lahan tiap komoditas dibuat dalam bentuk peta maka hasilnya seperti ini. 


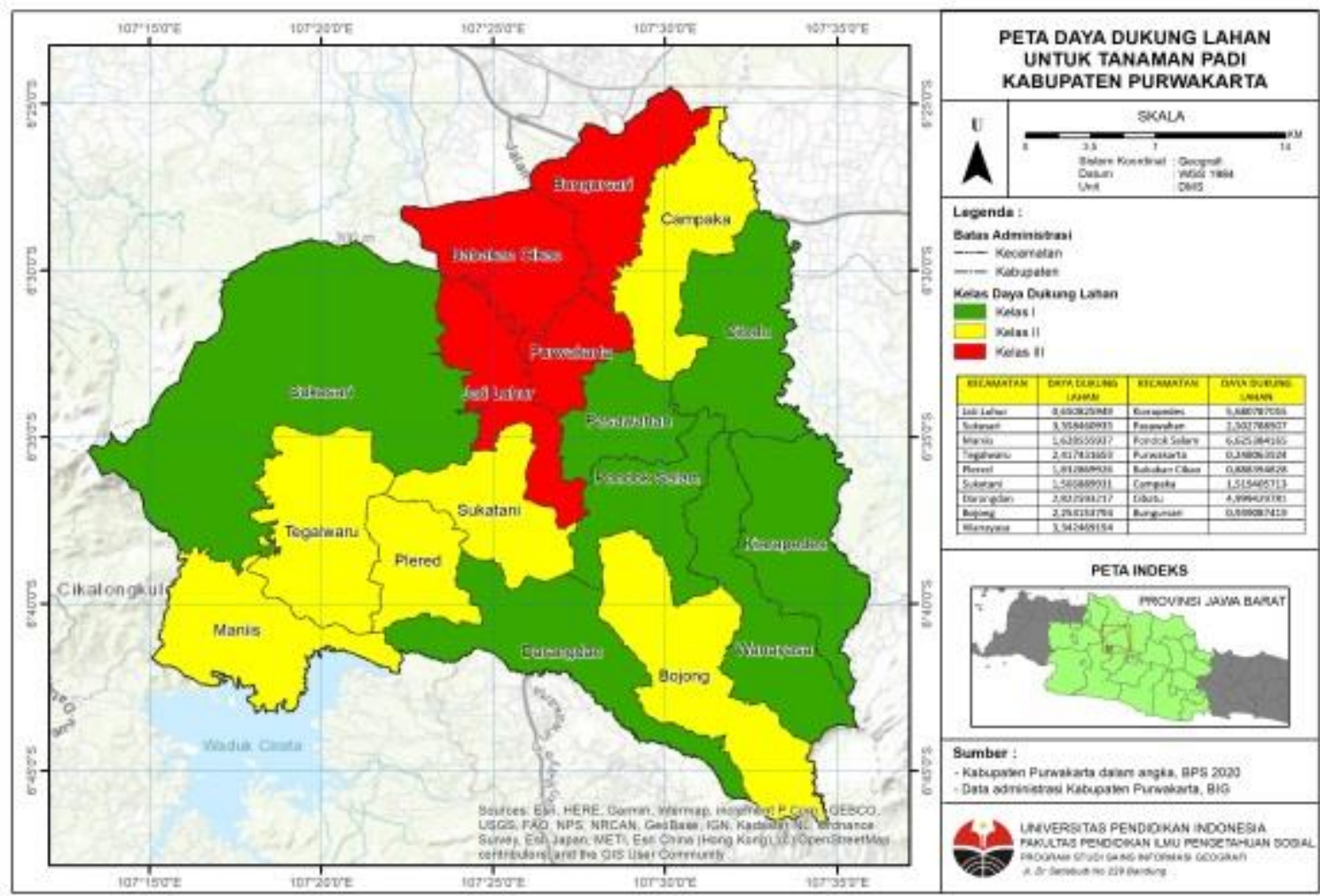

Gambar 1. Peta Daya Dukung Komoditas Padi

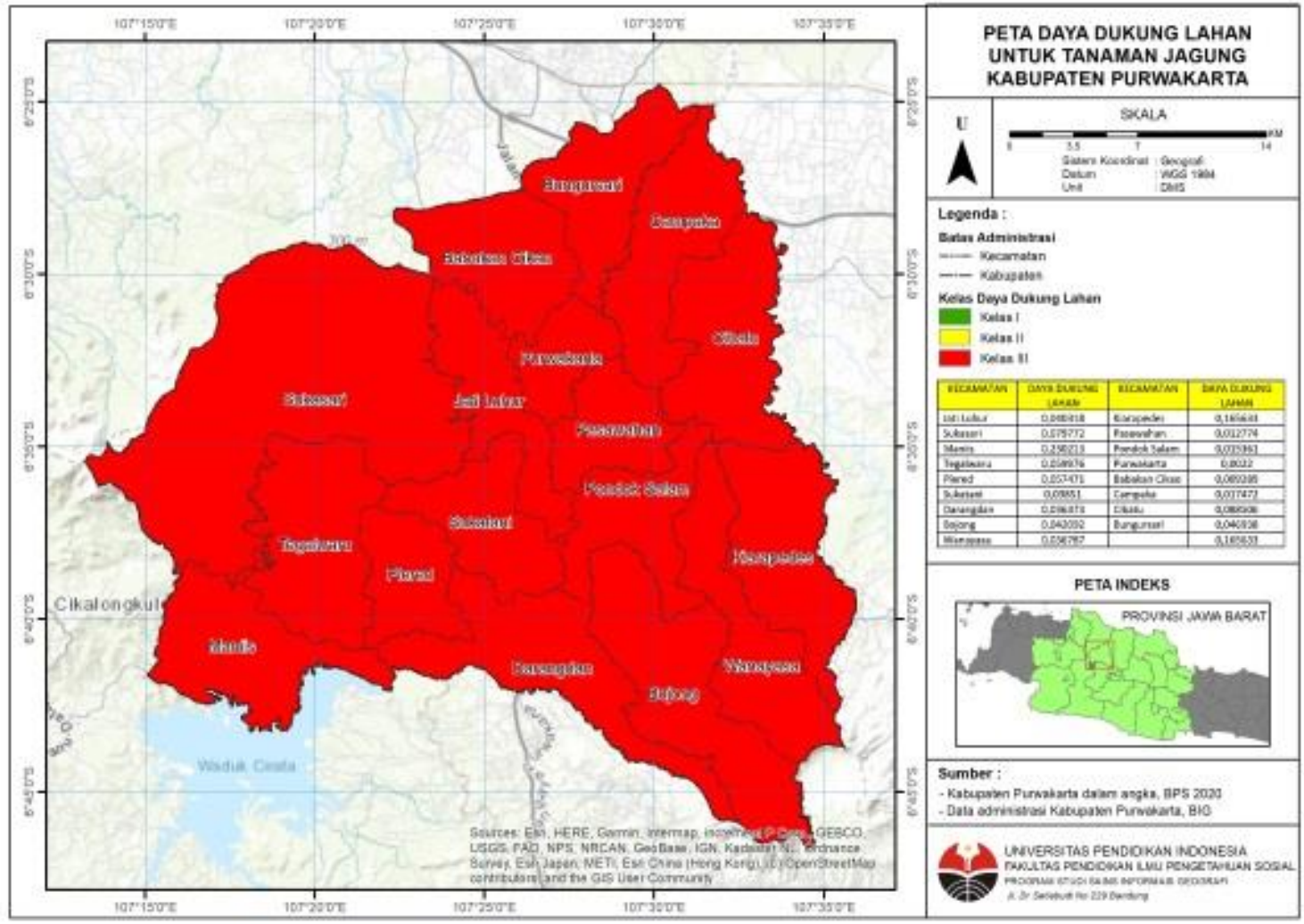

Gambar 2. Peta Daya Dukung Komoditas Jagung 
GEOGRAFI

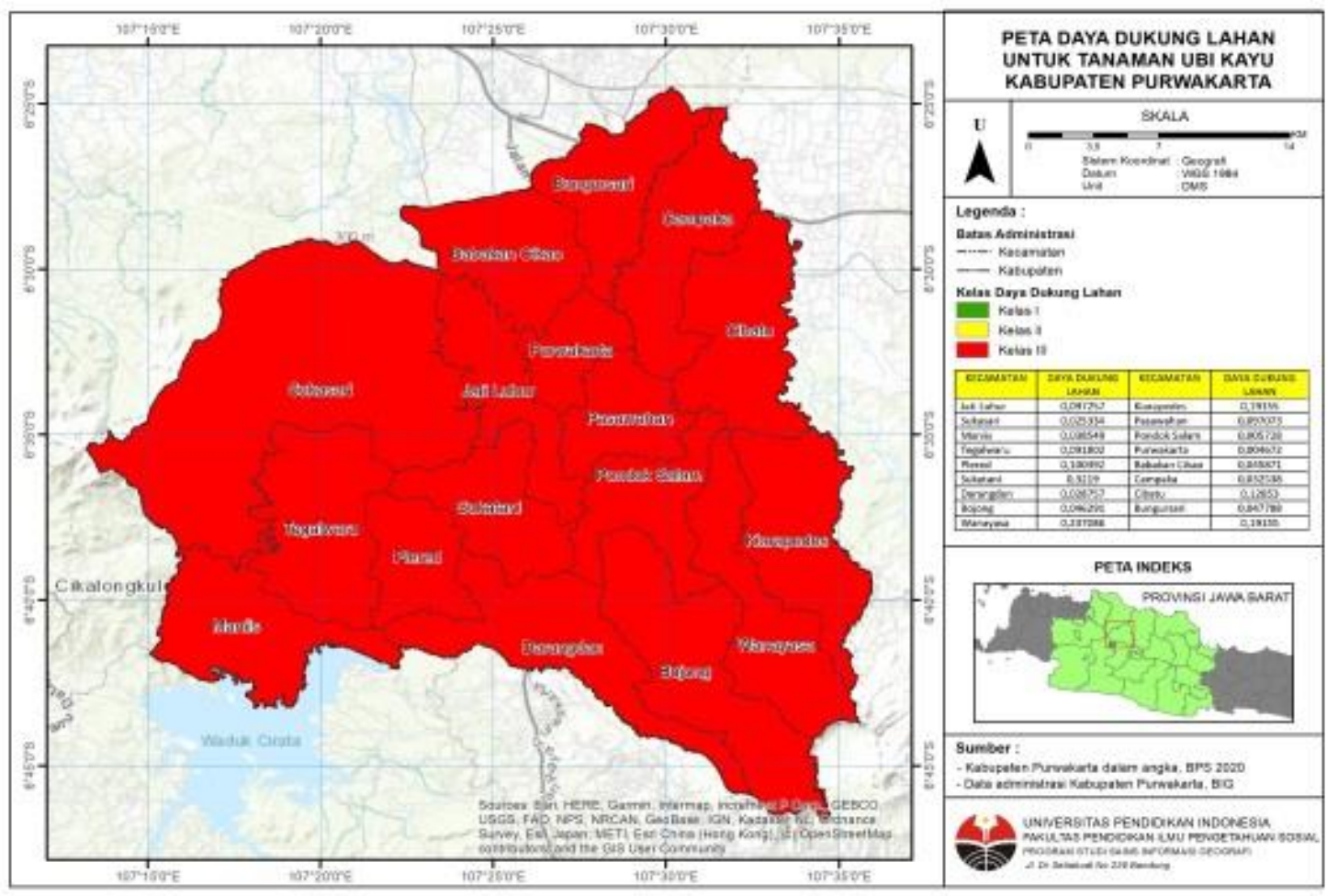

Gambar 3. Peta Daya Dukung Komoditas Ubi Kayu

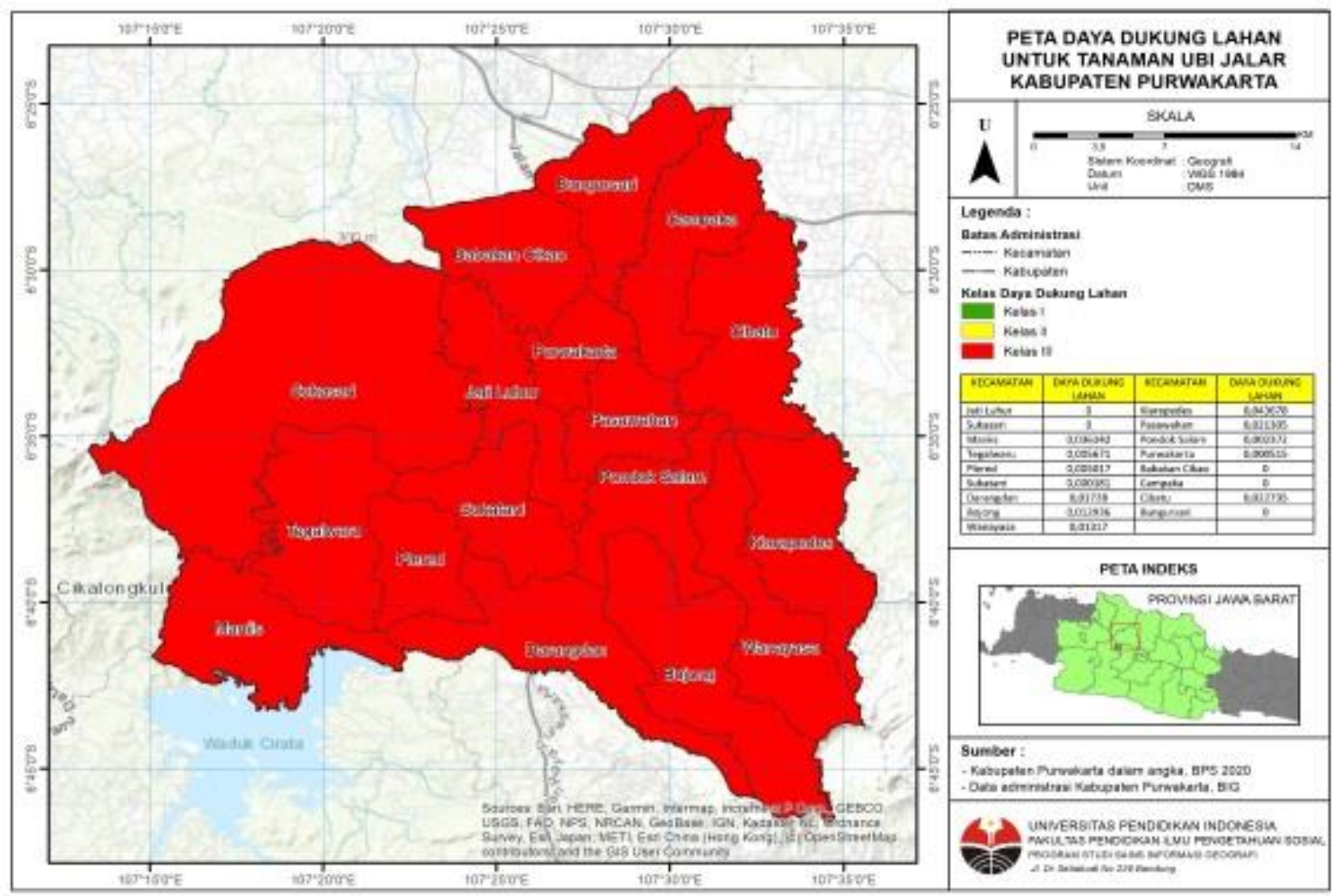

Gambar 4. Peta Daya Dukung Komoditas Ubi Jalar 
Rendahnya daya dukung lahan pada beberapa kecamatan sesuai dengan komoditasnya menunjukkan bahwa daya dukung lahan pertanian di Kabupaten Purwakarta perlu ditingkatkan baik dengan cara menekan jumlah penduduk maupun dengan cara meningkatkan kemampuan lahan pertanian agar bisa memberika hasil panen yang maksimal.

\section{Jumlah Penduduk Optimal Kabupaten Purwakarta}

Suatu wilayah dikatakan memiliki daya dukung lahan pertanian yang baik apabila wilayah tersebut mampu memberikan dan menjamin kelestarian pasokan pangan bagi penduduk yang tinggal di daerah yang bersangkutan serta masyarakatnnya mampu berswasembada pangan. Hal ini berarti bahwa terdapat jumlah penduduk tertentu yang mampu didukung kebutuhan pangannya oleh suatu lahan. Dengan demikian, seharusnya jumlah penduduk minimal seimbang dan/atau lebih kecil jumlahnya dibandingkan dengan ketersediaan lahan dan hasil panen di daerah tersebut.

Perhitungan JPO penting untuk dilakukan agar dapat diketahui berapa jumlah penduduk yang semestinya mampu didukung kebutuhan pangannya oleh lahan pertanian yang tersedia. Berdasarkan data jumlah penduduk dan hasil perhitungan daya dukung lahan pertanian tanaman pangan Kabupaten Purwakarta maka diperoleh jumlah penduduk optimal masing-masing kecamatan yang ditampilkan pada tabel 6 .

Tabel 6. Jumlah Penduduk Optimal Menurut Daya Dukung Lahan 2018.

\begin{tabular}{|c|c|c|c|c|c|c|}
\hline No & Kecamatan & Jumlah Penduduk & JPO Padi & JPO Jagung & JPO Ubi Kayu & JPO Ubi Jalar \\
\hline 1 & Jatiluhur & 70166 & 45666 & 2829 & 6824 & 0 \\
\hline 2 & Sukasari & 14631 & 49138 & 1167 & 371 & 0 \\
\hline 3 & Maniis & 34311 & 55877 & 7899 & 1323 & 1240 \\
\hline 4 & Tegalwaru & 45954 & 111091 & 2756 & 4219 & 261 \\
\hline 5 & Plered & 78361 & 143626 & 4503 & 7867 & 393 \\
\hline 6 & Sukatani & 69514 & 108921 & 2677 & 22377 & 13 \\
\hline 7 & Darangdan & 64356 & 181651 & 2341 & 1851 & 1112 \\
\hline 8 & Bojong & 47930 & 107994 & 2017 & 2219 & 620 \\
\hline 9 & Wanayasa & 42303 & 141396 & 1556 & 10029 & 557 \\
\hline 10 & Kiarapedes & 23249 & 132073 & 3851 & 4453 & 1015 \\
\hline 11 & Pasawahan & 44392 & 111104 & 567 & 4309 & 946 \\
\hline 12 & Pondoksalam & 27470 & 181999 & 422 & 157 & 65 \\
\hline 13 & Purwakarta & 191776 & 47573 & 422 & 896 & 99 \\
\hline 14 & Babakancikao & 57494 & 51077 & 534 & 2637 & 0 \\
\hline 15 & Campaka & 48681 & 73966 & 851 & 1584 & 0 \\
\hline 16 & Cibatu & 28756 & 143764 & 2545 & 3696 & 654 \\
\hline 17 & Bungursari & 64060 & 60158 & 3007 & 3061 & 0 \\
\hline
\end{tabular}

Hasil perhitungan yang ditampilkan pada Tabel 6, menunjukkan bahwa jumlah penduduk optimal di beberapa kecamtan sesuai komoditasnya masih lebih sedikit dibandingkan dengan jumlah penduduk yang terdata pada masing-masing kecamatan. Dengan demikian, diperlukan tambahan luas lahan panen maupun jumlah hasil panen untuk memenuhi kebutuhan penduduk yang ada di wilayah yang bersangkutan. Lahan-lahan kosong atau lahan terbuka perlu dimanfaatkan secara 
optimal untuk menanam tanaman pangan yang dapat membantu meningkatkan jumlah panen.

\section{Proyeksi Penduduk dan Kebutuhan Lahan Pertanian Tanaman Pangan Kabupaten Purwakarta.}

Proyeksi Kebutuhan Lahan Pertanian Tanaman Pangan pada penelitian untuk 10 tahun ke depan yang berarti untuk tahun 2028.

lahan pertanian di 10 tahun yang akan datang, agar mulai dari sekarang pemerintah setempat dapat melakukan perencanaan pembangunan, khususnya di bidang pertanian, untuk memenuhi kebutuhan pangan penduduk dengan lebih
Dengan hasil perhitungan daya dukung lahan di Kabupaten Purwakarta dan Jumlah Penduduk Optimal Kabupaten Purwakarta kita dapat mengetahui bahwa Kabupaten Purwakarta termagolong memiliki daya dukung lahan yang rendah dan jumlah penduduk optimal yang tidak sesuai dengan jumlah penduduk yang terdata.

Oleh karena itu, penelitian ini dapat membantu melihat bagaimana kondisi

baik. Berikut disajikan tabel dan grafik dari proyeksi jumlah penduduk tahun 2028, jumlah penduduk optimal tahun 2028, dan kebutuhan lahan pertanian tahun 2028 Kabupaten Purwakarta.

Tabel 7. Proyeksi Jumlah Penduduk Tahun 2028.

\begin{tabular}{|c|c|c|c|}
\hline No & Kecamatan & Jumlah Penduduk 2018 (Jiwa) & Jumlah Penduduk 2028 (jiwa) \\
\hline 1 & Jatiluhur & 70166 & 78656,086 \\
\hline 2 & Sukasari & 14631 & 14396,904 \\
\hline 3 & Maniis & 34311 & 37227,435 \\
\hline 4 & Tegalwaru & 45954 & 46735,218 \\
\hline 5 & Plered & 78361 & 86588,905 \\
\hline 6 & Sukatani & 69514 & 75909,288 \\
\hline 7 & Darangdan & 64356 & 68732,208 \\
\hline 8 & Bojong & 47930 & 51237,17 \\
\hline 9 & Wanayasa & 42303 & 45814,149 \\
\hline 10 & Kiarapedes & 23249 & 21668,068 \\
\hline 11 & Pasawahan & 44392 & 48120,928 \\
\hline 12 & Pondoksalam & 27470 & 28211,69 \\
\hline 13 & Purwakarta & 191776 & 219391,744 \\
\hline 14 & Babakancikao & 57494 & 68590,342 \\
\hline 15 & Campaka & 48681 & 55934,469 \\
\hline 16 & Cibatu & 28756 & 29474,9 \\
\hline 17 & Bungursari & 64060 & 78985,98 \\
\hline
\end{tabular}


Tabel 8. Jumlah Penduduk Optimal Tahun 2028.

\begin{tabular}{|c|c|c|c|c|}
\hline No & Kecamatan & Proyeksi Jumlah Penduduk Tahun 2028 & Daya Dukung Lahan Padi & JPO Proyeksi Penduduk Tahun 2028 \\
\hline 1 & Jatiluhur & 78656 & 0,650825949 & 51191 \\
\hline 2 & Sukasari & 14397 & 3,358460935 & 48351 \\
\hline 3 & Maniis & 37227 & 1,628555937 & 60627 \\
\hline 4 & Tegalwaru & 46735 & 2,417431659 & 112979 \\
\hline 5 & Plered & 86589 & 1,832869926 & 158706 \\
\hline 6 & Sukatani & 75909 & 1,566889931 & 118941 \\
\hline 7 & Darangdan & 68732 & 2,822593217 & 194003 \\
\hline 8 & Bojong & 51237 & 2,253153794 & 115445 \\
\hline 9 & Wanayasa & 45814 & 3,342469194 & 153132 \\
\hline 10 & Kiarapedes & 21668 & 5,680787055 & 123092 \\
\hline 11 & Pasawahan & 48121 & 2,502788907 & 120437 \\
\hline 12 & Pondoksalam & 28212 & 6,625384165 & 186913 \\
\hline 13 & Purwakarta & 219392 & 0,248063924 & 54423 \\
\hline 14 & Babakancika & 68590 & 0,888394828 & 60935 \\
\hline 15 & Campaka & 55934 & 1,519405713 & 84987 \\
\hline 16 & Cibatu & 29475 & 4,999429781 & 147358 \\
\hline 17 & Bungursari & 78986 & 0,939087419 & 74175 \\
\hline
\end{tabular}

Tabel 9. KLPR 2028.

\begin{tabular}{|c|c|c|c|}
\hline No & Kecamatan & KLPR 2028 & Luas Panen (ha) \\
\hline 1 & Jatiluhur & 3175 & 1146 \\
\hline 2 & Sukasari & 595 & 1263 \\
\hline 3 & Maniis & 1544 & 1441 \\
\hline 4 & Tegalwaru & 1897 & 2804 \\
\hline 5 & Plered & 3467 & 3576 \\
\hline 6 & Sukatani & 3082 & 2750 \\
\hline 7 & Darangdan & 2767 & 4547 \\
\hline 8 & Bojong & 2054 & 2692 \\
\hline 9 & Wanayasa & 1857 & 3563 \\
\hline 10 & Kiarapedes & 877 & 3324 \\
\hline 11 & Pasawahan & 1927 & 2766 \\
\hline 12 & Pondoksalam & 1129 & 4528 \\
\hline 13 & Purwakarta & 8819 & 1189 \\
\hline 14 & Babakancikao & 2806 & 1299 \\
\hline 15 & Campaka & 2298 & 1889 \\
\hline 16 & Cibatu & 1206 & 3657 \\
\hline 17 & Bungursari & 3280 & 1553 \\
\hline
\end{tabular}


wilayah swasembada pangan pada tahun 2028 , hal ini terjadi karena kebutuhan tersebut tidak dapat terpenuhi dengan hasil luas lahan panen yang ada. Sedangkan untuk kecamatan Sukasari, Tegalwaru, Plered, Darangdan, Bojong, Wanayasa, Kiarapedes, Psawahan, Pondoksalam, dan Cibatu masih bisa menjadi swasembada pangan untuk 2028 karena kebutuhan masih dapat terpenuhi dari luas lahan panen yang ada, dengan asumsi tidak terjadi konversi lahan pertanian menjadi lahan terbangun atau alih fungsi lahan pertanian menjadi fungsi lain. Hasil perbandingan di setiap kecamatan lebih jelasnya dapat dilihat pada Gambar 6.Peta KLPR 2028.

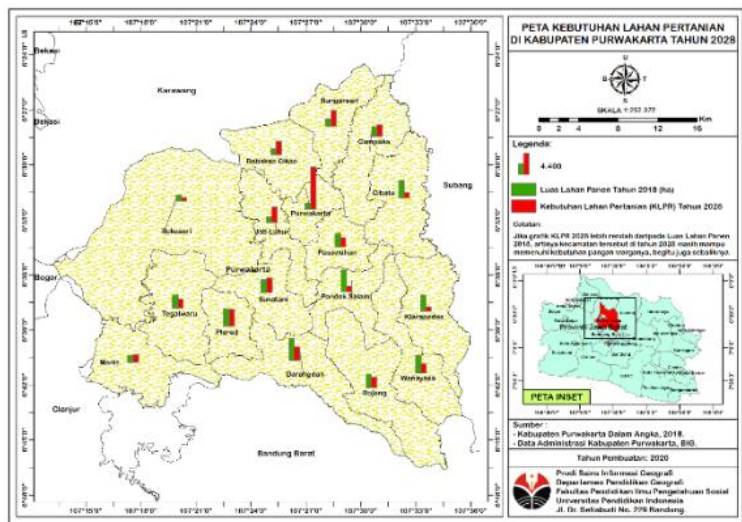

Gambar 6. Peta KLPR 2028.

\section{KESIMPULAN}

Berdasarkan uraian diatas hasil perhitungan daya dukung lahan pada komoditas padi, jagung, ubi kayu, dan ubi jalar untuk tiap kecamatan di kabupaten purwakarta tahun 2018, memiliki hasil tingkat daya dukung lahan yang bervariasi yang disebabkan oleh faktor data luas panen, produksi, dan jumlah penduduk pada tiap kecamatan tergantung pada komoditasnya. Pada daya dukung lahan padi di Kabupaten Purwakarta terdapat 6 kecamatan yang tergolong kelas 1 yang mampu swasembada pangan dan mampu memberikan kehidupan yang layak bagi daya dukung optimal diantaranya: Kecamatan Sukasari, Kecamatan Darangdan, Kecamatan Wanayasa, Kecamatan Kiarapedes, Kecamatan Pasawahan, dan Kecamatan Pondoksalam. Sedangkan untuk komoditas jagung, ubi kayu, dan ubi jalar seluruh kecamatan memiliki daya dukung lahan golongan kelas 3 artinya daya dukung lahan pertanian rendah.
Untuk hasil perhitungan jumlah penduduk optimal (JPO) dapat disimpulkan bahwa jumlah penduduk optimal di beberapa kecamatan Kabupaten Purwakarta apabila disesuaikan dengan komoditasnya masih lebih sedikit dibandingkan dengan jumlah penduduk yang terdata pada masing-masing kecamatan. Maka, diperlukan tambahan luas lahan panen maupun jumlah hasil panen untuk memenuhi kebutuhan penduduk yang ada di wilayah yang bersangkutan.

Untuk hasil perhitungan kebutuhan lahan pertanian dari perhitungan JPO 2028 dan KPLR 2028 dapat disimpulkan bahwa ada beberapa kecamatan di Kabupaten Purwarta yang tidak bisa menjadi wilayah swasembada pangan pada tahun 2028 diantaranya kecamatan Jatiluhur, Maniis, Sukatani, Purwakarta, Babakancikako, Campaka, dan Bungursari. Sedangkan untuk kematan yang lain masih bisa menjadi swasembada pangan untuk 2028 karena kebutuhan masih dapat terpenuhi dari luas lahan panen yang ada.

\section{DAFTAR PUSTAKA}

Badan Pusat Statistik. 2020. Kabupaten Purwakarta Dalam Angka 2020. Purwakarta: Badan Pusat Statistik.

Bappenas. 2015. Evaluasi Implementasi Kebijakan Lahan Pertanian Pangan Berkelanjutan. Direktorat Pangan dan Pertanian, Bappenas. Jakarta

Dinas Pangan dan Pertanian Kaupaten Purwakarta [Daring] Tersedia di: https://pertanian.purwakartakab.go.id/tent ang-distanhutbun/ [Diakses 4 Juni 2020]

Imam Arifa'illah Syaiful Huda, M. H. (2017). Analisis Daya Dukung dan Kebutuhan Lahan Pertanian Di Kabupaten Lamongan Tahun 2035. Prosiding Seminar Nasional Geografi UMS , (hal. 396-405). Surakarta.

Kabupaten Purwakarta. [Daring] Tersedia di: https://westjavainc.org/municipal/kabupat enpurwakarta/\#: :text=Lokasi\%20Geogra fis\&text=Luas\%20wilayah\%20Kabupate n\%20Purwakarta\%20adalah,\%2C28\%25 $\% 20$ per $\% 2$ Dtahun.\&text=Kabupaten $\% 20$ Purwakarta\%20memiliki\%20motto\%20 Wibawa\%20Karta\%20Raharja. [Diakses 9 Juni 2020)

Moniaga, V. R. (2011). Analisis Daya Dukung Lahan Pertanian. ASE, Vol 7 (2), 61-68. 
Muta'ali. 2015. Teknik Analisis Regional Untuk Perencanaan Wilayah, Tata Ruang dan Lingkungan. Yogyakarta: Badan Penerbit Fakultas Geografi Universitas Gadjah Mada.

Nurmalina, Rita. 2008. Keberlanjutan Sistem Ketersediaan Beras Nasional: pendekatan teknik ordinasi rap-rice dengan metoda multidimensional scaling (mds). Departemen Agribisnis, Fakultas Ekonomi dan Manajemen, IPB.

Soerianegara, I. 1978. Pengelolaan Sumberdaya Alam Bagian I dan II. Sekolah Pasca Sarjana IPB.
Sonny. 2013. Pengertian Daya Dukung Lahan Serta Faktor-Faktor Penentu Dan FaktorFaktor Penghambat. [Daring] Tersedia di: http://sonnylazio.blogspot.com/2013/01/penge rtian-daya-dukung-lahanserta.html\#: :text=Menurut $\% 20$ Manik $\% 2$ 0(2003\%3A12),\%2C\%20buatan\%2C\%20 dan\%20manusia). [Diakses 9 Juni 2020)

Yunita Lisnawati, A. W. (2009). Analisis Daya Dukung Lahan Di Kawasan Puncak Kabupaten Bogor. Jurnal Penelitian Hutan Tanaman, Vol 6 (1), 45-54. 